\title{
ACHIEVEMENTS OF LITHUANIAN SUSTAINABLE DEVELOPMENT DURING THE INTEGRATION PROCESS INTO THE EUROPEAN UNION
}

\author{
Genovaitė Liobikiené $\dot{1}^{1}$ Justina Mandravickaité ${ }^{2}$
}

\author{
${ }^{1,2}$ Vytautas Magnus University, Vileikos g. 8, LT-44404 Kaunas, Lithuania \\ E-mails: ${ }^{1}$ g.liobikiene@gmf.vdu.lt (correspondingauthor); ${ }^{2}$.mandravickaite@pmf.vdu.lt
}

Received 07 June 2010; accepted 10 January 2011

\begin{abstract}
After the collapse of the Soviet Union, Lithuania rapidly started turning towards European trade patterns averting from those of the former communist regime. However, European integration has had an effect not only on convergence of gross domestic product (GDP) but also on convergence of prices as well as on alteration of living standards. The goals of Lithuanian integration to the EU were noted in the National Lithuanian Sustainable Development Strategy. The key objective of sustainable development in Lithuania was to achieve the present developmental level of the EU countries according to indicators of economic and social development. Therefore, the paper compares the convergence across the old and newer member-states of the EU in terms of GDP, household final consumption expenditure and comparative price level indices. In addition, it is revealed that Lithuanian expenditure patterns rapidly approach those of the old member-states of the EU. Consequently, Lithuanian integration to the EU contributes to approaching the EU-15 level what means the successful achievements of Sustainable Development Strategy as well. So, the aim of this paper is to show how successful are Lithuanian sustainable development achievements in terms of GDP, comparative price level and household expenditure within framework of integration to the EU.
\end{abstract}

Keywords: sustainable development, convergence, economic integration, gross domestic product (GDP), comparative price level, living standards.

Reference to this paper should be made as follows: Liobikienè, G.; Mandravickaitè, J. 2011. Achievements of Lithuanian sustainable development during the integration process into the European Union, Technological and Economic Development of Economy 17(1): 62-73.

JEL Classification: Q56, R20, P22, P24.

\section{Introduction}

Sustainable development (SD) is considered the main vision of further development of society. Therefore, the concept of SD has become an important objective for policy makers (Singh et al. 2009). The Brundtland report defines the sustainable development as "development that meets 
the needs of the present generation without compromising the ability of future generations to meet their own needs" (WCED 1987). Thereby, the aim of SD is to improve the life quality of the present population in a way that will not have a negative impact on future generations. Planning for SD is ultimately related with combining, balancing or trade-off aspects of these economic, social, environmental (and also institutional) dimensions (Moles et al. 2008).

In terms of implementing SD, there are two categories of states commonly distinguished to start with: developed and developing countries. Very rapid growth in population, poverty, gender inequality, education, and medical service problems are characteristics of developing countries. The developed countries mostly face such problems as excessive consumption of natural resources and environmental pollution. At the same time, both - developing and developed - countries have one very important common development feature: their progress is based on natural evolution patterns, however, economic and welfare growth has proceeded at a very different rate.

SD Strategy in Lithuania was approved in 2003. The strategy takes into account peculiarities of Lithuania as a country with an economy in transition. The main objective of SD in Lithuania is by 2020 to achieve the present (2003) developmental level of the EU countries according to indicators of economic and social development as well as the efficiency in consumption of resources not exceeding allowable standards of environmental pollution of the EU. Achieving the level of GDP and living standards of the EU old countries is the main objective in SD Strategy. Therefore, Lithuanian implementation of SD is directly correlated with the Lithuanian membership in the EU, as Lithuania's development will be mainly influenced by eurointegration. However, Lithuania together with other Central and Eastern European countries has covered a surprisingly long distance from being the part of the Soviet Bloc to becoming member-states of the European Union in an extremely short period of time in history (Berend 2007).

After the year 1989 and the collapse of the communist regimes, the system of values in the Central and Eastern European countries has been significantly altered by major changes in the political and economical domains (Kyriazis, Zouboulakis 2005). East-Central European countries began their transition from the 'Soviet-type' towards 'Western-type' states (Aidukaite 2009). This transition period began with 'shock therapy' (Kolodko 2009). Williamson (2005) pointed out that this process occurred by very fast privatization. Furthermore, Eastern European countries had classical economic system of the Soviet Union with centrally planned regulation which was incapable of working in accordance with the principles of capitalism (Adam et al. 2009). Consequently, this institutional legacy maintains an "economic environment that discourages increasing productivity" (Kyriazis, Zouboulakis 2005). The collapse of the communist regimes brought to an end not only a particular type of political system but above mentioned planned economy as well (Aidukaite 2009). Paths to economic reform and democracy-based systems took on different forms. As Hungary, Poland and the Czech Republic went ahead with rapid transformation processes, many countries in Eastern Europe entered less constructive cycles of economic reform (Mockaitis 2005).

Three Baltic States - Lithuania, along with Latvia and Estonia, were the first to call for independence from the Soviet Union (Miazhevich 2009). They chose a model of dependence on Western European nations as well. Having suffered through radical neoliberal transformation, the Baltic States have sharply diversified their trade patterns away from the region of former 
Soviet Union towards those of the European Union (Tsygankov 2007). The roadblock which kept them from being 'Europeans' no longer exists (Berend 2007). The dream of Central and Easter European countries to 'join Europe' was realized on the 1st of May, 2004. Europeanization quickly became the driving force which is still being implemented in distinct degrees in the countries throughout the region (Mockaitis 2005).

Membership in the EU was of great importance for accelerating the rate of growth by institutional, financial and investment benefits resulting from the old member-states of the European Union (Kolodko 2009). Doyle and Fidrmuc (2006) investigated two broad categories of effects that occurred in the new member-states. First, they can take full advantage of economic integration within the European Single Market through free movement of goods. Second, as argued and documented empirically by Mayda and Rodrik (2005), the new members will also be included in the EU-wide system of redistribution, including the Structural and Cohesion funds and the Common Agricultural Policy (CAP). Eligibility for regional aid is directly related to the countries' and regions' level of economic development (Doyle, Fidrmuc 2006). Thereby, the EU promotes market economy (Brauers et al. 2007). However, most people in the region found themselves bitter and disappointed (Berend 2007). As a result, the disappointment of the majority of citizens and business elites were realized in occasional protests that emerged against the rising prices, the closedowns of ineffective domestic industries and the loss of national sovereignty (Andreev 2009).

Therefore, European integration has had an effect across the member-states of the EU not only on convergence of GDP (Welsch, Bonn 2008; Palan, Schmiederberg 2010) but also on convergence of prices (Méjean, Schwellnus 2009) and on alteration of values as well. Cultural change in post-communist societies normally considered to have been adopted on very different stances in relation to Western business values (Miazhevich 2009). Berend (2007) stressed that after the year 1989 the existing traditional value system was overturned by adopting the Western lifestyle, freedom, consumerism and other attributes. Money became the only measure of the value of life's success. A poor living standard which is clearly reflected by the high percentage of household expenditure for such basic products as food and drink has changed apparently as well (Berend 2007).

Therefore, the aim of this paper is to show how successful are Lithuanian SD achievements within framework of integration to the EU. Focusing on convergence of GDP as one of the main indicators of economical development, household final consumption expenditure and comparative price level indices in the old EU-15 and the newer EU-25 countries is motivated by the fact that it would reveal Lithuanian expectations of integration to the EU. Considering eight new Central and Eastern European countries is important because an equalization of above mentioned indicators is stated as an objective of European integration. The main focus of this paper is quantitative assessment of the differences in GDP, comparative price level indices and household final consumption expenditure between Lithuanian and the EU-15 average. It shows Lithuanian achievements in implementing SD strategy. Investigation of household expenditure by categories reveals alteration of living standards in Lithuania before and after accession into the EU as well.

The paper is organized as follows. After introduction, the second part is devoted to the data and methods issues. Third part gives the overview of convergence in EU-15 and EU-25 
as well as the analysis of Lithuanian and other seven Central and Eastern European countries achievements towards integration into the EU. Moreover, in this part it is presented Lithuanian expenditure patterns as well. Finally, the conclusions are drawn in the last part of paper.

\section{Investigation data and methodology}

The methodology used in this study is composed of three parts and the research covers the period of 1995-2007, which concerns situation before integration into the EU (1995-2004), accession into the EU in 2004 and a post-integration time-period (2004-2007) till the world economic crisis. First, the analysis attempts to evaluate the convergence in old EU-15 and newer EU-25 member-states in terms of GDP, expenditure of household final consumption and comparative price level indices. These indicators have been taken on such importance because they provide an important source of information about economic and welfare growth rate. GDP reveals economic welfare of particular country. Thereby, GDP is used in Purchasing Power Standards (PPS) per capita instead of market exchange rate in order to convert currencies what gives possibility to compare the output of economies and their welfare in real terms (that is control over differences in price levels) (International Comparison Program 2005). The expenditure of household final consumption is used in PPS per capita as well and this indicator shows society welfare and consumption level. The comparative price level indices is framed as ratio what gives possibility to compare prices in relation to the average of the EU-15 (EU-15 $=100 \%)$. If index is higher than 100, it means that certain country is very expensive in comparison with average of the EU-15. Respectively, if index is between 100 and 50, it means that particular country is relatively expensive, and if index is lower than 50, it means that particular country is cheap (European Economic Statistics 2008).

In order to identify convergence, this paper suggests using the variance as the preferred measure of dispersion since it allows attributing convergence or divergence in corresponding movements of macroeconomic conditions. The extent in terms of variance shows a decreasing pattern of the explanatory variables over the time, so one can identify convergence and vice versa (Welsch, Bonn 2008).

Thereinafter, this paper compares eight Central and Eastern European countries (Latvia, Estonia, Lithuania, Hungary, Slovenia, Slovakia, Check Republic and Poland) in terms of GDP, expenditure of household final consumption and comparative price level indices in comparison with average level of the EU-15. Thus, in order to analyze the behavior of economies over time, one needs to use volume index of changes. To evaluate the economic growth of particular country the most used indicator is the volume change of GDP in PPS. This indicator avoids exchange rate movements, evolution of domestic prices and population changes in certain country. Besides, the same factors are involved in comparison of all the other countries of the EU (European Economic Statistics 2008). The volume indexes of GDP, expenditure of household final consumption and comparative price level indices indicate different achievements of particular countries towards successful integration into the EU.

Finally, the main focus of this paper is devoted to Lithuanian GDP, household expenditure, comparative price level indices and patterns of household expenditure by categories. It is presumed that after accession of Lithuania into the EU and implementing SD strategy altered not 
only its GDP or prices but expenditure patterns as well. To identify alteration of expenditure patterns of Lithuania, it is used Lithuanian household expenditure by category at constant price index per inhabitant (year $2000=100 \%$ ).

All data were collected mainly from Statistical Office of the European Union (Eurostat).

\section{Results}

\subsection{Convergence of the EU countries}

After joining the EU, Lithuania's one of the key ambitions is to get closer to the standard of the EU-15 old member-states. Achieving the level of GDP and living standards of the EU old countries is the main objective in SD strategy. However, primarily it is essential to examine convergence of the EU-15 across above mentioned indicators. The evidence of convergence across the old member states of the EU, which is attributed to the extent of GDP, prices and household expenditure variance could reveal convergence of newer member-states in the EU model. This subsection is dedicated to the evaluation of the variance across old EU-15 and newer EU-25 in terms of GDP, household final consumption expenditure rate and comparative price level indices.

According to Fig. 1, the variances of old EU-15 countries in terms of GDP, household final consumption expenditure and comparative price level were distinct. During the analyzed period the dispersions of all indicators fluctuated. Notwithstanding these fluctuations, during the whole period household final consumption expenditure and comparative price level tended to converge. The household final consumption expenditure rate shows a steady convergence since 2002 onward. The comparative price rate converged quickly until 1997, whereas later the dispersion remained almost constant, reflecting a common and relatively low rate of comparative prices. This stands in contrast to GDP per capita which displays the behavior of divergence.

Therefore, the experience of the EU old member-states in 1995-2004 showed that the largest convergence was noticed in comparative prices level. It depends on Single Market Program (SMP) (Méjean, Schwellnus 2009). The model of European price convergence al-

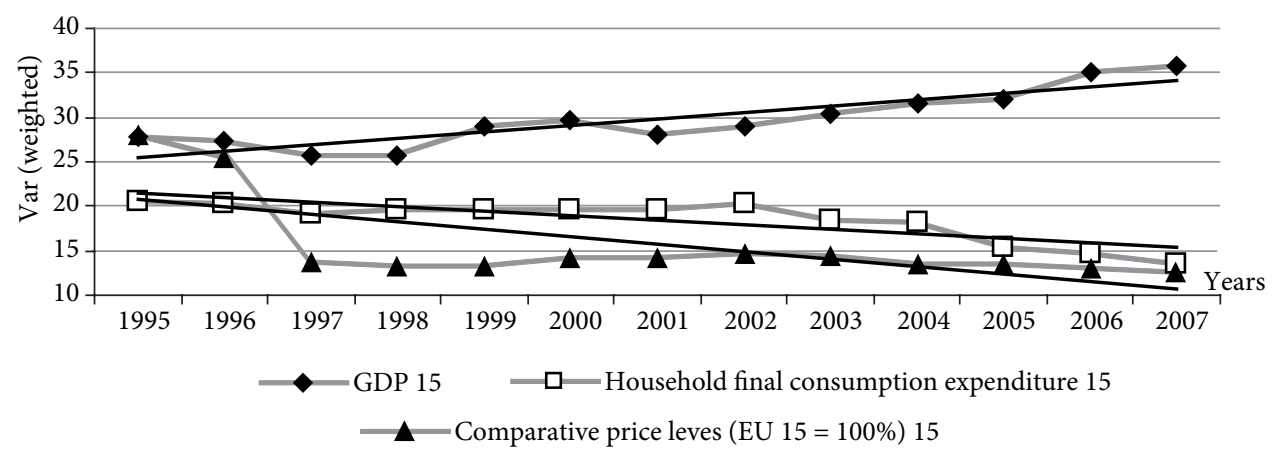

Fig. 1. EU-15 variances of GDP, household final consumption expenditure and comparative price level $(\mathrm{EU}-15=100 \%)$. Trend lines are shown to guide an eye 
lows elaborating the price impact on product market integration into two margins. At the intensive margin, it may reduce price discrimination within-firm through an increase in the cost of segmented markets. At the extensive margin, product market integration may lead to reduction of the fixed costs of entering European export markets. The adoption of common currency has led to gradual removal of trade and production barriers within Europe as well (Méjean, Schwellnus 2009; Palan, Schmiederberg 2010).

Respectively, the similar result of divergence in GDP was observed by Fung (2009) and Welsch and Bonn (2008). Fung (2009) estimated that about $60 \%$ of the cross-country variation in growth rates of per-capita of GDP is attributable to differences in productivity growth. Palan and Schmiederberg (2010) pointed out that in development of European countries Southern Europe, comparing with other parts of Western Europe, has lost its comparative advantages in low technology industries. As mentioned by Aghion et al. (2004) and by Fung (2009), financial constraints prevent poor countries from taking full advantage of technology transfers and cause them to diverge from the growth rate of the European frontier. Also as noted Kaitila (2004), the divergence in GDP is strongly associated with the fast growth in Luxemburg (Welsch, Bonn 2008).

Depending on this model, post-Soviet countries should be capable of integrating into the EU. Therefore, it suggests that prices in the newer member-states of the EU most likely should get closer to the average of the old member-states, while household final consumption expenditure would reach the convergence more slowly. Conversely, the convergence concerning GDP should not be as desired.

Thus, when it is considered the variance after the EU enlargement by ten new memberstates including Lithuania (Fig. 2), results revealed that the aforementioned observation remains valid. The largest convergence of three above mentioned indicators was noticed in comparative prices, whereas the convergence in GDP continues to be almost constant. Rogers (2007) asserted that there could be further reductions of price dispersion in Europe where the price convergence problem could be at the top of the public agenda (WolszczakDerlacz 2008). In addition, Méjean and Schwellnus (2009) confirmed that integration may have increased price convergence within the union while maintaining large price differences between the EU and the rest of the world. So, achieving convergence in terms of GDP appears to be more difficult than the EU conceived.

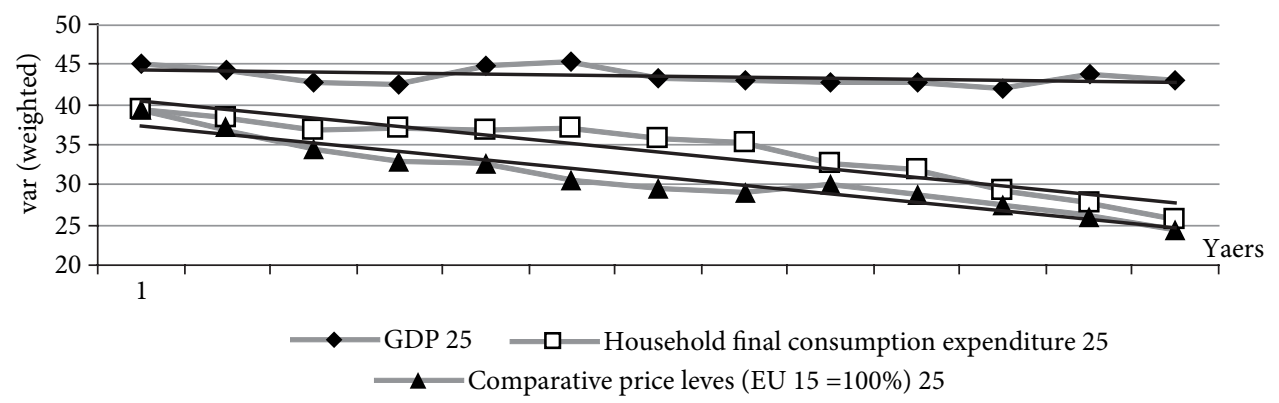

Fig. 2. EU-25 variances of GDP, household final consumption expenditure and comparative price level (EU-15 $=100 \%)$. Trend lines are shown to guide an eye 
Considering this background, the following subsection will address the GDP, household final consumption expenditure and comparative price level of eight Central and Eastern European countries in comparison with EU-15 average.

\subsection{Comparative results of Central and Eastern European countries}

Before entering the EU, all eight Central and Eastern European countries confronted with differences in starting points (Raim 2005). All countries had particular period of preparations to joining the EU (1995-2004). According to statistical data on GDP, Estonia was the most successful in reaching the average GDP of the EU-15 (difference by 19\%). Lithuania and Latvia followed it by achieving GDP with difference of $13 \%$ and $12 \%$ respectively. Other new member-states of the EU go as follows: Slovenia came closer to average GDP of the old member-states by $11.9 \%$, Hungary - by $11.3 \%$, Slovakia - by $8.8 \%$, Poland - by $7.9 \%$, the Czech Republic - by 3.5\%. However, candidate countries display considerable economic disparities (Doyle, Fidrmuc 2006). A comparison between Central and Eastern European countries and EU-15 in 2004 revealed that in terms of GDP per capita in Slovenia and the Czech Republic it was around three-quarters of the old EU-15 average while in Latvia, Lithuania and Poland it was less than half, respectively (Hondroyiannis et al. 2008).

After accession into the EU and by the year 2007, it is observed faster GDP growth in Estonia and Slovakia. Estonia in the period between 2004 and 2007 rose from 12400 PPS to 17100 PPS per capita and Slovakia rose respectively from 12300 PPS to 16900 PPS per capita. The lowest GDP growth was in Hungary and Poland from 13700 PPS to 15600 PPS per capita and from 11000 PPS to 13600 PPS per capita, respectively. However, comparing Central and Eastern European countries with EU-15 average in terms of GDP in 2007 was observed that Slovenia and the Czech Republic remained the most developed new member-states because GDP of those countries retained around three-quarters of the EU-15 average. Latvia, Lithuania and Poland remained less developed countries, however, for the present with more than half of old EU-15 countries average in terms of GDP.

Regarding to distribution of household final consumption expenditure, Slovenia and the Czech Republic in 2004 belonged to the group of Central and Eastern European countries with the highest household expenditure per capita. Conversely, in Latvia, Lithuania and Poland expenditure for household consumption was the lowest. Accordingly, the same results were noticed in terms of GDP. However, during the period after accession to the EU (2004-2007), the greatest growth of household final expenditure was observed in Latvia and Lithuania by $38 \%$, and by $30 \%$ respectively. The lowest growth of household expenditure was noticed in Hungary and Slovenia: by $10 \%$ and by $14 \%$ accordingly. Nevertheless, comparing household final consumption expenditure of Central and Eastern European countries with EU-15 average in 2007, Slovenia and the Czech Republic remained with the highest household expenditure. On the other hand, Poland and Hungary became countries with the lowest household expenditure compared with the average of the EU-15. It needs stressing that Latvia and Lithuania approached the average of EU-15 more rapidly in household expenditure than in GDP. It is possible to assume that it could be caused by rapid price boost or by growing wealth, or by alteration of people lifestyle. Regarding to this, people spent out money instead of saving it. 
In terms of the percentage of comparative price level indices, which is expressed as a ratio and makes it possible to compare prices in relation to the EU-15 average (EU-15 = 100\%), Lithuania, Latvia and Estonia were ranked among the cheapest European countries at the beginning of preparation to the accession into the EU (Raim 2005; Mockaitis 2005). However, in 2004 in all Central and Eastern European countries comparative price was higher than 50 what means countries were relatively expensive in comparison with the EU-15 average (European Economic Statistics 2008). It is interesting to note that after becoming member-states in 2004 and by the year 2007 Latvia approached the average of the EU-15 by the very $10.4 \%$. Respectively, Estonia got closer to the average by $9.9 \%$, Poland - by $8.6 \%$, Slovakia - by $8.2 \%$, the Czech Republic - by $7 \%$, Lithuania - by $6.4 \%$, Hungary - by $4.9 \%$, Slovenia - by $3.8 \%$. However, Slovenia with Estonia remained the most expensive countries Central and Eastern European countries, whereas Lithuania and Poland maintained positions of the cheapest countries.

\subsection{Comparative results of Lithuania}

Considering only Lithuanian situation, Fig. 3 shows that in the beginning of preparation to accession into the EU GDP, household final consumption expenditure and comparative price level indices consisted of share amounting to one-third of the EU-15 average. During the preparation period from 1995 to 2004, it was observed the rapid growth of comparative price level, and in 2004 it consisted of the biggest share, amounting to more than half of total EU-15 average. Meanwhile, GDP and household expenditure only attempted to reach this level. After accession into the EU in 2004-2007 the situation changed. GDP and comparative price level grew further and gradually approached the average of the EU-15. However, household final consumption expenditure rose more rapidly. And thus, in 2007 Lithuania was the most successful in approaching the EU-15 in the sector of household expenditure. It is strangely enough that in 2007 Lithuania remained the cheapest country but with high level of household expenditure, thereby, rapid price boost was unsupported. Therefore, as it was mentioned above, it could depend on alteration of people's lifestyle and values. Berend (2007) explained that after joining the EU the traditional, existing value system was overturned by the leading Western lifestyle, freedom, and consumerism. Consequently, the above mentioned results draw interference that Lithuanian integration to EU contributes to approach of EU-15 countries level and it means the successful achievement in implementing SD likewise.

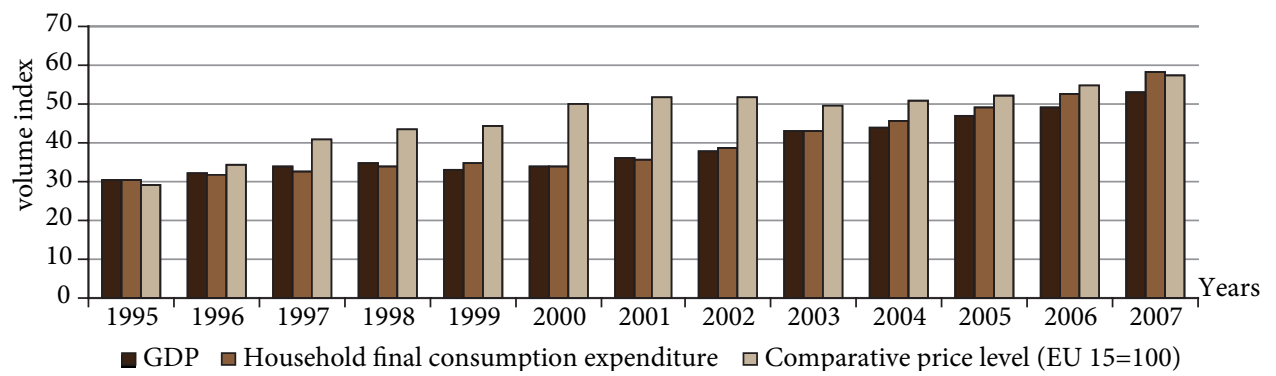

Fig. 3. Lithuanian volume index of GDP, household final consumption expenditure and comparative price level, compared with EU-15 countries average level 
Considering Lithuanian living standard, after the collapse of the former Soviet Union and before accession to the EU, Lithuania was one of lagged countries in the EU region. A poor living standard was clearly reflected by a high percentage of household expenditure spent for basics as food drink and housing (Berend 2007). In 1995 in Lithuania this percentage estimated three-quarters of the total expenditures. However, during analyzed period of 1995-2007, the situation was changed by market liberalization, multiple-choice possibilities. Besides, growing incomes highly influenced Lithuanian household expenditure structure. Thereby, Lithuanian household expenditure structure was following Western expenditure patterns. Dagiliūte and Liobikienè (2008) showed that as a consequence of improved living standards in Lithuania from 1996 to 2006 the percentage of household expenditures devoted to food declined by 1.8 times. Nonetheless, it composed the biggest share amounting to more than one-third of total expenditure. However, the biggest increase of expenditure was observed for recreation and culture as well as for transport by 1.8 and 2.2 times, respectively. Nevertheless, in 2006 both reached $11 \%$ of the total expenditure separately. Therefore, comparing Lithuanian and EU-15 structures of household expenditures it was observed that Lithuanian composition becomes more similar to the EU-15. For example, in 2006 the EU-15 countries' household expenditure for housing was accounted for $23 \%$, meanwhile Lithuanian expenditure for housing was $20 \%$. For mobility, EU-15 countries were accounted for $22 \%$, Lithuanian - 17\%. The biggest disparity in household expenditure between Lithuania and the EU-15 countries was observed in expenses for leisure activities, food and drink. Though expenditure for food and drink in Lithuania took larger share, and expenditure for recreation and leisure activities was smaller than in the EU-15 countries, the Lithuanian household expenditure structure tends to change (Dagiliūtè, Liobikienè 2008).

Thereby, as it can be observed in Fig. 4, during the analyzed period, comparing with the year 2000, the expenditure for clothing and footwear as well as recreation and culture increased the most. On the other hand, expenditure for housing, food and drink grew the least during the same period of time. Accordingly, expenditure for health care and transport was gradual.

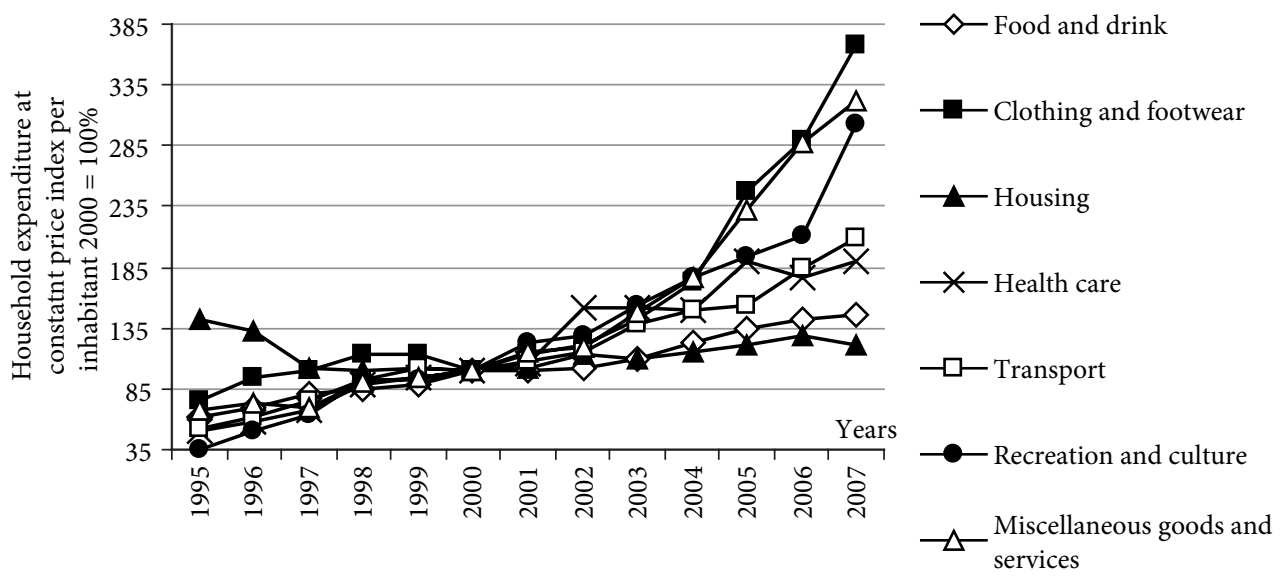

Fig. 4. Lithuanian household expenditure by category at constant price indices per inhabitant (year $2000=100 \%$ ) 
It can be argued that Lithuanians like all other citizens of the EU started spending more and more on luxury commodities. Indeed, according to patterns of expenditures less was spent on food while more money was kept for recreation and culture. This latter perspective thus concludes that the patterns of Lithuanian expenditure reveal the rapid approach to those of the old member-states of the EU living standard. Forasmuch as achieving the living standards of the EU old countries is the main objective in SD strategy, the latter perspective means the successful achievement in implementing sustainable development strategy as well. Nevertheless, the more detailed investigation of Lithuanian achievement realizing sustainable development strategy within other social and environmental indicators is needed as the analysis of Lithuanian living standard remains the main aim of further research in this field.

\section{Conclusions}

This paper has analyzed Lithuanian achievements in sustainable development and integration process into the EU which is related to these achievements. With respect to the second set of issues, the convergence in GDP, comparative price level indices and household final consumption expenditure were estimated across the old and newer member-states of the EU. Considering to those indicators of convergence and volume index of newer eight member-states, it was revealed Lithuanian expectations of integration to the EU. The estimated quantitative assessment of the differences between Lithuanian and the EU-15 average in household expenditure by categories, which allows to uncover living standard, showed Lithuanian successful achievements in implementing SD Strategy.

The most important findings can be summarized as follows:

1. During the analyzed period across the old and newer member states of the EU the largest convergence was observed of comparative price level indices, while GDP convergence was the least.

2. After the EU enlargement and until 2007 Slovenia and the Czech Republic remained the most developed new member-states with the highest household expenditure. Latvia, Lithuania and Poland remained less developed countries. Poland and Hungary became countries with the lowest household expenditure. The tendency of Slovenia and Estonia as of the most expensive countries persisted, whereas Lithuania and Poland maintained positions of the cheapest countries.

3. In Lithuania during the preparation period from 1995 to 2004 it was observed the rapid growth of comparative price level indices, and in 2004 it consisted of the biggest share. After accession into the EU in 2004-2007, GDP and comparative price level indices grew gradually, however, household final consumption expenditure rose more rapidly. In 2007 Lithuania was the most successful in approaching the EU-15 average in the terms of household final consumption expenditure

4. According to patterns of expenditure, the Lithuanians spent less on food and more for recreation and culture. So, the patterns of Lithuanian living standards rapidly approached to those of the old member-states of the EU and it demonstrated the successful achievement in implementing SD Strategy. 


\section{References}

Adam, F.; Kristan, P.; Tomšič, M. 2009. Varieties of capitalism in Eastern Europe (with special emphasis on Estonia and Slovenia), Communist and Post-Communist Studies 42: 65-81. doi:10.1016/j.postcomstud.2009.02.005

Aghion, P.; Howitt, P.; Mayer-Foulkes, D. 2004. The effect of financial development on convergence theory and evidence. NBER working paper 10358.

Aidukaite, J. 2009. Old Welfare State Theories and New Welfare Regimes in Eastern Europe: Challenge and Implication, Communist and Post-Communist Studies 42: 23-39. doi:10.1016/j.postcomstud.2009.02.004

Andreev, A. S. 2009. The unbearable lightness of membership: Bulgaria and Romania after the $2007 \mathrm{EU}$ accession, Communist and Post-Communist Studies 42: 375-393. doi:10.1016/j.postcomstud.2009.07.001

Berend, I. T. 2007. Social shock in transforming Central and Eastern European, Communist and PostCommunist Studies 40: 269-280. doi:10.1016/j.postcomstud.2007.06.007

Brauers, W. K. M.; Ginevičius, R.; Zavadskas, E. K; Antuchevičienè, J. 2007. The European Union in a transition economy, Transformations in Business \& Economics 6(2): 21-37.

Dagiliūte, R.; Liobikienè, G. 2008. Sustainable household consumption: The state and perspectives in Lithuania, in Sustainable Consumption 2008 Conference; Corvinus University of Budapest, Hungary; October 8, 2008: Academic conference proceedings, 50-61.

Doyle, O.; Fidrmuc, J. 2006. Who favors enlargement? Determinants of support for EU membership in the candidate countries' referenda, European Journal of Political Economy 22: 520-543. doi:10.1016/j.ejpoleco.2005.09.008

European Economic statistics. 2008. Eurostat European commission Eurostat Statistical books.

Fung, M. K. 2009. Financial development and economic growth: Convergence or divergence?, Journal of International Money and Finance 28: 56-67. doi:10.1016/j.jimonfin.2008.08.001

Hondroyiannis, G.; Swamy, P. A. V. B.; Tavlas, G. S. 2008. Inflation dynamics in the euro area and in new EU members: Implications for monetary policy, Economic Modeling 25: 1116-1127. doi:10.1016/j.econmod.2008.02.002

International Comparison program. 2005. Global purchasing power parities and real expenditure.

Kaitila, V. 2004. Convergence of real GDP per capita in the EU15: how do the accession countries fit in?, ENEPRI Working Paper No. 25.

Kolodko, G. W. 2009. A two-thirds of success. Poland's post-communist transformation 1989-2009, Communist and Post-Communist Studies 42: 325-351. doi:10.1016/j.postcomstud.2009.07.005

Kyriazis, N. C.; Zouboulakis, M. S. 2005. Modeling institutional change in transition economies, Communist and Post-Communist Studies 38: 109-120. doi:10.1016/j.postcomstud.2005.01.004

Mayda, A. M.; Rodrik, D. 2005. Why are some people (and countries) more protection than others?, European Economic Review 49: 1393-1430. doi:10.1016/j.euroecorev.2004.01.002

Méjean, I.; Schwellnus, C. 2009. Price convergence in the European Union: Within firms or composition of firms, Journal of International Economics 78: 1-10. doi:10.1016/j.jinteco.2009.02.008

Miazhevich, G. 2009. Hybridisation of business norms as intercultural dialogue: The case of two PostSoviet countries, Communist and Post-Communist Studies 42: 181-198. doi:10.1016/j.postcomstud.2009.04.008

Mockaitis, I. A. 2005. The race to EU integration: How many and how high are the hurdles?, International Business and Finance 19: 1995-1999.

Moles, R.; Foley, W.; Morrissey, J.; O’Regan, B. 2008. Practical appraisal of sustainable development Methodologies for sustainability measurement at settlement level, Environmental Impact Assessment Review 28: 144-165. doi:10.1016/j.eiar.2007.06.003 
National Strategy for Sustainable Development of the Republic of Lithuania 2003. Government of the Republic of Lithuania.

Palan, N.; Schmiederberg, C. 2010. Structural convergence of European countries. Structural Change and Economic Dynamics (in press). doi:10.1016/j.strueco.2010.01.001

Raim, J. 2005. Former Soviet Union as the world champion in cheapness, International Business and Finance 19: 333-349. doi:10.1016/j.ribaf.2004.12.007

Rogers, J. H. 2007. Monetary Union, price level convergence and inflation: How close is Europe to USA?, Journal of Monetary Economics 54: 785-796. doi:10.1016/j.jmoneco.2006.01.004

Singh, R. K.; Murty, H. R.; Gupta, S. K.; Dikshit, A. K. 2009. An overview of sustainability assessment methodologies, Ecological Indicators 9: 189-217. doi:10.1016/j.ecolind.2008.05.011

Tsygankov, A. P. 2007. Modern at last? Variety of weak states in the post-Soviet world, Communist and Post-Communist Studies 40: 423-439. doi:10.1016/j.postcomstud.2007.10.006

Welsch, H.; Bonn, U. 2008. Economic convergence and life satisfaction in the European Union, The Journal of Socio-Economics 37: 1153-1167. doi:10.1016/j.socec.2006.12.072

Williamson, J. 2005. Differing interpretation of the Washington consensus, Distinguished Lectures Series 17. Leon Kozminski Academy of Entrepreneurship and Management, Warsaw. Available from Internet: $<$ www.tiger.edu.pl/publikacje/dist/wiliamson.pdf $>$.

Wolszczak-Derlacz, J. 2008. Price convergence in the EU - an aggregate and disaggregate approach, International Economics and Economic Policy 5(1-2): 25-47. doi:10.1007/s10368-008-0104-1

World Commission on Environment and Development (WCED). 1987. Our Common Future. Oxford University Press, Oxford.

\section{LIETUVOS DARNAUS VYSTYMOSI PASIEKIMAI VYKSTANT INTEGRACIJAI I EUROPOS SĄJUNGĄ}

\section{G. Liobikienè, J. Mandravickaitė}

Santrauka. Žlugus Sovietų Sąjungai, Lietuva greitai perėmė europietiškajj̣ modelį, atsisakydama plačiai paplitusio sovietinejje sistemoje. Taigi integracija ị Europos Sąjungą pasireiškẻ ne tik BVP konvergencija, bet ir supanašèjusiomis kainomis bei gyvenimo lygio pokyčiais. Lietuvos integracijos ị Europos Sąjungą tikslai buvo išdèstyti Nacionalineje darnaus vystymosi strategijoje. Pagrindinis Lietuvos darnaus vystymosi tikslas buvo pasiekti Europos Sąungos senųjų valstybių narių lygị pagal atitinkamus ekonominius ir socialinius rodiklius. Straipsnyje lyginama konvergencija senose ir naujose Europos Sajungos šalyse. Konvergencijai nustatyti pasirinkti šie trys rodikliai: BVP, namų ūkio išlaidos ir palyginamụjų kainų indeksas. Be to, surinkti duomenys parodè, kad Lietuva pagal išlaidų struktūrą sparčiai vejasi senąsias ES valstybes nares. Taigi, integracija ị ES Lietuvai padeda vytis ES-15 lygị ir tuo pat metu reiškia sèkmingą darnaus vystymosi strategijos igyvendinimą. Pagrindinis straipsnio tikslas - atskleisti Lietuvos darnaus vystymosi laimejjimus pagal BVP, palyginamųjų kainų indekso bei namų ūkio išlaidų rodiklius vykstant integracijai į ES.

Reikšminiai žodžiai: darnus vystymasis, konvergencija, ekonominè integracija, BVP, palyginamųjų kainų lygis, gyvenimo lygis.

Genovaitė LIOBIKIENĖ. PhD student at Vytautas Magnus University, Department of Environmental Sciences, Lithuania. Research interests: sustainable development, sustainable consumption and environmental awareness.

Justina MANDRAVICKAITE். Student at Vytautas Magnus University, Department of Public Communications, Lithuania. Research interests: integration into the EU, sustainable development. 